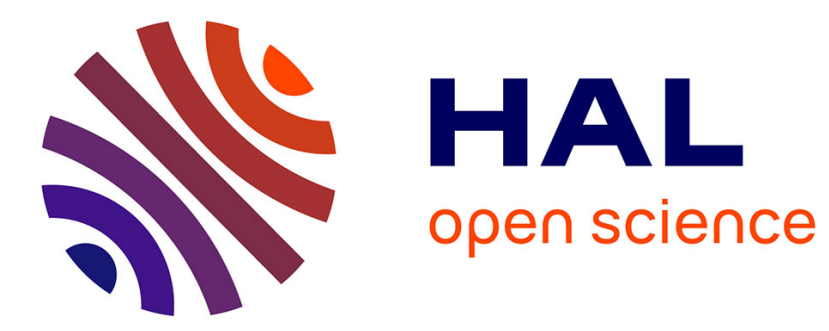

\title{
Shaping Future Digital Citizens in Aotearoa/New Zealand Schools: Vision and Challenges
}

Nicki Dabner

\section{To cite this version:}

Nicki Dabner. Shaping Future Digital Citizens in Aotearoa/New Zealand Schools: Vision and Challenges. 11th IFIP World Conference on Computers in Education (WCCE), Jul 2017, Dublin, Ireland. pp.13-18, 10.1007/978-3-319-74310-3_2 . hal-01762852

\section{HAL Id: hal-01762852 \\ https://hal.inria.fr/hal-01762852}

Submitted on 10 Apr 2018

HAL is a multi-disciplinary open access archive for the deposit and dissemination of scientific research documents, whether they are published or not. The documents may come from teaching and research institutions in France or abroad, or from public or private research centers.
L'archive ouverte pluridisciplinaire HAL, est destinée au dépôt et à la diffusion de documents scientifiques de niveau recherche, publiés ou non, émanant des établissements d'enseignement et de recherche français ou étrangers, des laboratoires publics ou privés. 


\title{
Shaping Future Digital Citizens in Aotearoa/ New Zealand Schools: Vision and Challenges
}

\author{
Nicki Dabner \\ University of Canterbury e-Learning Lab, New Zealand \\ nicki.dabner@canterbury.ac.nz
}

\begin{abstract}
The New Zealand Ministry of Education promotes the use of digital technologies in schools to support future-focused learning and to achieve the vision for New Zealand young people, as stated in the national school curriculum document, to become confident, connected, actively involved, lifelong learners. This vision statement, extended in meaning since its inception in 2007 to further encompass the development of digital citizens, has influenced the strategic direction for educational developments in New Zealand and is supported by a range of Ministry of Education initiatives. However, a number of challenges have arisen that impact the ability for New Zealand educators to fully implement this vision in schools. This short paper presents a review of literature that illustrates the vision for young citizens in New Zealand, and describes some current challenges faced by New Zealand educators as they aim to realize this vision in complex digitally enhanced environments.
\end{abstract}

Keywords. Digital citizen; vision; future-focussed education; initiatives; challenges

\section{Introduction}

This short paper addresses two contemporary themes identified as focus areas for WCCE 2017: strategy and policy in education contexts and settings, and shaping the future for 'digital citizens'. These themes are currently being explored by the author within an interpretive case study investigating how educators within one Aotearoa/New Zealand school endeavours to foster the development of their students as future 'digital citizens'. The following focus questions were addressed within the broader literature review informing this study: what was the proposed vision for the development of digital citizens within the Aotearoa/ New Zealand education system, and what challenges appear to impact the realisation of this vision in school settings. This paper presents a brief overview of literature illustrating the vision and challenges associated with the shaping of future 'digital citizens' in Aotearoa/ New Zealand schools.

\section{The Vision within the New Zealand Education System}

The New Zealand Ministry of Education published a discussion document in 2015 that illustrated a proposed vision for New Zealand education in 2025. This vision 
exemplified a "highly connected, interdependent education system that equips students with the skills for the future, fosters students' identity, language and culture, and prepares students to participate as successful citizens in the $21^{\text {st }}$ century" [1]. The evolution of this vision and the use of digital technologies in schools in New Zealand has been progressive, but amplified with the introduction of the current national 'New Zealand Curriculum'[2] document in 2007, where notions of connectivity, futurefocus, citizenship, globalisation and e-learning were embedded.

In 2012, a New Zealand research team analysed findings from ten years of research on practices and future thinking in education to identify emerging themes for future-oriented teaching and learning. It was intended this would inform the development of the Ministry's vision for a $21^{\text {st }}$ century education system. In their subsequent report, 'Supporting Future-oriented Learning and Teaching: A New Zealand Perspective' [3], the authors used the term 'wicked problems' [4] to describe complex, value-laden issues that "span multiple domains; social, economic, political, environmental, legal and moral" and proposed that all levels of the educational ecosystem needed support to develop the capacities required for 'wicked problemsolving'. They further proposed that $21^{\text {st }}$ century education must focus upon the development of learners' dispositions, capacities and competencies so they are able to "deal with new situations and environments, including those with a high degree of complexity, fluidity and uncertainty”. They concluded with three key ideas to inform future policy development and strategies for 21st century learning in New Zealand: education for diversity supported by connectivity and connectedness, and coherence in the development of a shared vision for $21^{\text {st }}$ century schooling.

In 2013, the Associate Minister of Education formed a reference group who examined 21st century learning principles in order to identify priorities that would transform teaching and learning in New Zealand, enabled by technologies that are becoming increasingly ubiquitous in society. The reference group proposed that equipping learners with 21st century skills and digital competencies would require significant change within the New Zealand education system and that a cohesive, coordinated, cross-sector and multi-stakeholder approach would be required to support this change. The subsequent 2015 Ministry document 'Towards Digital Fluency' [5] described a number of initiatives designed to "ensure all schools are equipped with state-of-the art infrastructure, teachers get the resources and support they needed to be digitally fluent, and every student benefits from the advantages of digital technologies for learning”. Digital fluency and ensuring safe, secure online learning environments were identified as priorities in the document and a Ministry commitment made to enable digital access for all learners in New Zealand "regardless of location, learning needs or family background" [5].

The Ministry's commitment to the vision of young people as digital citizens continues today, with the Minister of Education announcing in 2016 that Digital Technology would be fully integrated into The New Zealand Curriculum document by 2018, the first change made to the curriculum since its publication in 2007. The Minister stated that this change would "ensure that we have an education system that prepares children and young people for a future where digital fluency will be critical for success.” 


\section{Challenges to Achieving the Vision}

Digital literacy must be addressed in schools to enable young people to become effective digital citizen. Student use of digital technologies has attracted the attention of researchers since digital technologies first became accessible in schools and homes. Researchers interested in this area have studied digital technology use by students in educational environments [6, 7, 8], home/informal environments [9] and across both environments [10]. Although the nature of many of these studies were initially regarded as oppositional (i.e. home versus school), they are increasingly becoming complimentary as the boundaries between technology use at home and school become less distinct $[11,12]$.

As opportunities for New Zealand students to use digital technologies inside and outside of the school environment increase, there has been an associated call for educators across the education sector in New Zealand to ensure students are equipped with the knowledge, skills and attitudes that enable them to engage effectively and safely in the digital realm within and beyond the school environment [13]. Digital citizenship provides a recognised framework to address these issues; however digital citizenship is not specified within the current New Zealand Curriculum document, nor mandatory for schools to address. Netsafe, an independent non-profit organisation in New Zealand supported by the Ministry of Education, and Ministry of Justice, assert that there has never been a greater need for schools and communities in New Zealand to work together in this area, as reliance on digital technologies escalates. In their 2016 'Digital Challenges and New Zealanders' Report [14], they proposed that creating safe online environments in education was becoming increasingly complex, as educators were "faced with the double challenge of integrating these technologies in a way that benefits education and maintains the safety of children and their data online”. Posed as a 'big question' looking forward to 2016, Netsafe advocated that further developments for online safety measures needed to be multi-stakeholder collaborations and enterprises between industry, government, parents/whanau and schools, with a shift from "protective strategies towards those that promote healthy development of online behaviours". Netsafe also signalled important information for schools following the introduction of the Harmful Digital Communications Act [15], passed by the New Zealand Parliament in 2015. The introduction of this act is important for the Boards of Trustees, elected parents from the community who adopt the role of governors, managers and employers in New Zealand schools, as they are required by law to provide a safe physical and emotional environment for students and staff. If harmful communications are posted to an online service hosted by a school, the board may be held legally responsible. A school can be considered to be hosting if they manage an online environment where content is posted. This can include school website with comments sections, social media sites, blogs and apps that enable comments. These practices are becoming increasingly common in New Zealand primary schools. The act also provides avenues for individuals to report upon and organise the removal of harmful digital communications (e.g. material posted on websites and blogs, social media, emails and texts). School leaders are now able to contact Netsafe, with the permission of the individual, to report an issue. Criminal charges are now possible in serious instances for people over the age of fourteen, so students need to be very aware of potential implications if they are involved in 
incidents of cyberbullying or harassment of another individual. Netsafe also provides support to schools and parents to address cyberbullying.

The increased use of technologies in schools also presents challenges to teachers across at all levels of the educational arena [16], many of whom indicate they lack the knowledge, skills and understandings required to educate their students, and that they struggle to keep up with the impact of changes in the increasingly digital landscape [17]. A 2014 report published by Research New Zealand [18] indicated that the rate of technological change and professional development required in schools was challenging for staff, with only $14 \%$ of Principals indicating they believed all of their teachers had the skills to effectively manage the use of digital devices to support learning. These findings were endorsed in a 2014 New Zealand Council for Education Research [19] report. Findings revealed that although $70 \%$ of teachers indicated that their increased use of ICT to support learning was an achievement, 38\% indicated students' learning was limited by their own knowledge and skills. In addition, 56\% expressed concern about emergent safety issues and 55\% were finding their working day had extended.

Challenges achieving the vision to develop $21^{\text {st }}$ century digital citizens in schools also exist for those involved in initial teacher education in New Zealand, because they are also expected to prepare new teachers for digitally enhanced classrooms and increasingly collaborative teaching practices. Chai and Lim [20] acknowledged the complexity teacher educators face when proposing that pre-service teachers need to learn how to use digital technologies and manage the complexities of using them in classrooms, at the same time as developing beliefs, understandings, agency and a sense of teacher identify. Koehler and Mishra [21] added complexity by adding the need to develop TPACK; technological pedagogical and content knowledge, appropriate new pedagogical ideas, and refine their ability to apply these ideas. Instefjord and Munthe [22] offer pedagogical compatibility and social awareness to this complex list of requirements, plus the imperative to address this in an integrated manner. Add critical digital literacies and digital citizenship to this package and the complexity increases again.

\section{Discussion and Conclusion}

Although both the proposed and current vision for young people to become effective digital citizens in New Zealand education are laudable, cohesive strategies and continued resourcing is needed to address issues that may hinder the ability for this vision to be realised. Netsafe have brought digital citizenship to the forefront in education by producing a white paper in 2016 entitled 'From Literacy to Fluency to Citizenship: Digital Citizenship in Education' [23]. They suggest that the proliferation of terms and abstract concepts used in education in New Zealand have impeded developments in this area and call for 'a consensus view' of the values, aims and knowledge underpinning these terms' so schools can move forwards with some common understanding and address this increasingly important area. Multiple opportunities for professional development must be available for teachers and resourcing provided for schools, to ensure their teachers are supported, and have the time to develop their skills, understandings and practices. Digital technologies and 
environments will continue to evolve and change is inevitable, thus resourcing will be an on-going requirement. Those involved in initial teacher education will need to ensure they are keeping pace with the changes in schools as they attempt to implement this vision for $21^{\text {st }}$ century learning, and adjust programmes if required to encompass these changes. Staff in initial teacher education contexts may also require access to professional development and have time to be able to develop their own knowledge, skills and understandings [24]. This again has resourcing implications.

To conclude, the literature suggests that all members of the education sector in New Zealand will be required to become 'confident, connected, actively involved, lifelong learners' for the New Zealand vision for digital citizens to be fully realized. How this happens across the education sector provides fertile ground for research in New Zealand. This research will also be valuable in other countries, not least because of the high esteem in which the New Zealand curriculum is held.

Acknowledgements. The author would like to acknowledge the support provided by the university to enable the author to present this paper at the conference.

\section{References}

1. Ministry of Education.: New Zealand Education in 2025; Lifelong Learners in a Connected World (Draft). Ministry of Education, Wellington (2015) http://www.education.govt.nz/assets/Documents/Ministry/Initiatives/Lifelonglearners.pdf

2. Ministry of Education.: The New Zealand Curriculum. Ministry of Education, Wellington (2007) http://nzcurriculum.tki.org.nz/The-New-Zealand-Curriculum

3. Bolstad, R., Gilbert, J., McDowall, S., Bull, A., Boyd, S., Hipkins, R.: Supporting Futureoriented Learning and Teaching - A New Zealand Perspective. Report for the Ministry of Education. NZCER, Wellington (2012) https://www.educationcounts.govt.nz/publications/schooling/109306

4. Rittel, H., Webber, M.: Dilemmas in a General Theory of Planning. Policy Sciences, 4, 155-169 (1973) http://www.cc.gatech.edu/fac/ellendo/rittel/rittel-dilemma.pdf

5. Ministry of Education.: Towards Digital Fluency (2015) http://www.education.govt.nz/assets/Uploads/Towards-Digital-Fluency.pdf

6. Levy, R., Yamanda-Rice, D., March, J. Digital Literacies in the Primary Classroom. In; Hall, K., Cremin, T., Comber, B., Moll. (eds.) International Handbook of Research on Children's Literacy, Learning and Culture, First Edition, 333-343. Wiley \& Sons (2013)

7. Otrel-Cass, K., Cowie, B, Khoo, E.: The SCIAnTICT Project: Technology-Enhanced Teaching and Learning of Primary Science. SET: Research Information for Teachers, no. 3, 26-31 (2015)

8. De Abreau, B.: Changing Technology=Empowering Students through Media Literacy Education. New Horizons in Education, 58(3), 26-33 (2010)

9. McPake, J., Plowman, L., Stephen, C.: Pre-school Children Creating and Communicating with Digital Technologies in the Home. British Journal of Educational Technology, 44(3), 421-431 (2015)

10. Jesson, R., Meredith, M., Rosedale, N.: Reconsidering Home Learning in the Digital Learning Environment: The Perspective of Parents, Students and Teachers. SET Research Information for Teachers, no. 3 (2015)

11. Bjørgen, A., Erstad, O.: The Connected Child: Tracing Digital Literacy from School to Leisure, Pedagogies: An International Journal, 10:2, 113-127 (2015) 
12. Plowman, L.: Rethinking Context: Digital Technologies and Children's Everyday Lives. Children's Geographies, 14(2), 190-202 (2016)

13. The $21^{\text {st }}$ Century Learning Reference Group.: Future-focussed Learning in Connected Communities: A Report by the $21^{\text {st }}$ Century Learning Reference group (2014)

14. Netsafe New Zealand.: Digital Challenges and New Zealander: A Focus Upon the Incident Reports and Queries Made to Netsafe in 2015. Netsafe, Auckland (2016), https://www.netsafe.org.nz/safer-internetday/documents/SID2016_DigitalChallengesReport2015.pdf

15. New Zealand Parliamentary Council Office.; Harmful Digital Communications Act 2015. http://www.legislation.govt.nz/act/public/2015/0063/latest/whole.html

16. Davis, N.E., Eickelmann, B., Zaka, P.: Restructuring of Educational Systems in the Digital Age from a Co-evolutionary Perspective. Journal of Computer Assisted Learning, 29(5), 438-450 (2013)

17. New Zealand Parliament Education and Science Select Committee.: Inquiry into $21^{\text {st }}$ Century Learning Environments and Digital Literacy (1.2a), Report of the Education and Science Committee (2012), https://www.parliament.nz/resource/0000243164

18. Research New Zealand.: Digital Technologies in New Zealand Schools: A Report Prepared for the 2020 Communications Trust (2014), http://2020.org.nz/wpcontent/uploads/2014/07/Digital-Technologies-in-School-2014-FINAL.pdf

19. Wylie, C., Bonne, L.: Primary and Intermediate Schools in 2013: Main Findings from the NZCER National Survey. New Zealand Council for Educational Research, ISBN 978-1927231-35-7 (2014)

20. Chai, C. S., Lim, C. P.: The Internet and Teacher Education: Traversing Between the Digitized World and Schools. The Internet and Higher Education, 14(1), 3-9 (2011)

21. Koehler, M.J, Mishra, P.: What is Technological Pedagogical Content Knowledge? Contemporary Issues in Technology and Teacher Education, 9(1), 60-70 (2009)

22. Instefjord, E., Munthe, E.: Preparing Pre-service Teachers to Integrate Technology: An Analysis of the Emphasis on Digital Competence in Teacher Education Curricula. European Journal of Teacher Education, 39(1), 77-93 (2016)

23. Netsafe New Zealand.: From Literacy to Fluency to Citizenship: Digital Citizenship in Education. White paper. Netsafe, Auckland, (2016), https://www.netsafe.org.nz/wpcontent/uploads/2016/11/NETSAFE-WHITEPAPER-From-literacy-to-fluency-tocitizenship.pdf

24. Duncan-Howell, J.: Digital Mismatch: Expectations and Realities of Digital Competency Amongst Pre-service Education Students. Australian Journal of Educational Technology, 28(5), 827-840 (2012) 